\title{
Novo Logotipo para Fibromialgia
}

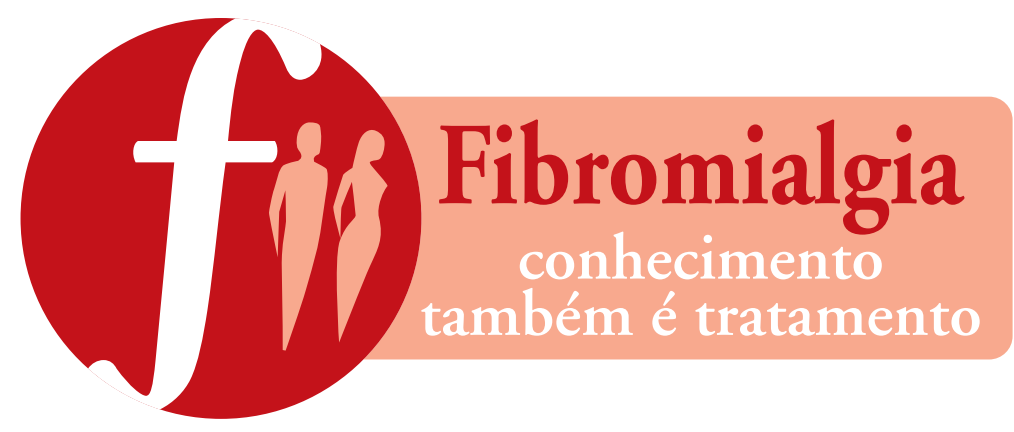

Durante reunião realizada pela comissão de dor e fibromialgia da Sociedade Brasileira de Reumatologia (SBR), em meados de 2005, surgiu a idéia de criar um logotipo simbolizando a fibromialgia (FM) com a finalidade de ser utilizado em campanhas educativas e eventos científicos. Embora existisse a clássica figura do corpo nu feminino com os pontos dolorosos destacados, tão amplamente divulgada em capítulos de livros sobre a síndrome e na maioria das aulas em congressos, e que parecia ser o sinônimo gráfico da FM, esta não traduzia os conceitos mais atuais que temos: FM é mais comum em mulheres, mas não é raro em homens, e indivíduos com dor difusa e sem pontos dolorosos podem ter FM. Além disso, a elaboração oficial de um logotipo pela SBR seria uma forma de nos reafirmarmos como os especialistas desta enfermidade.

Assim, iniciada sua elaboração, decidimos ousar, utilizando uma linguagem mais moderna e abstrata que simboliza a FM, e sem impor, ao mesmo tempo, o corpo feminino e os pontos dolorosos.

Esse processo envolveu todos os membros da comissão que participaram democraticamente, votaram e comemoraram o resultado, que agora é publicado em primeira mão.

A data oficial para seu lançamento será dia 12 de maio de 2006, considerado mundialmente como o "dia da fibromialgia".

\section{VALÉria VALIM}

Professora Doutora da Escola de Medicina da Santa Casa de Misericórdia, Universidade Federal do Espírito SANTo (UFES)

\section{Roberto Ezequiel Heymann}

Assistente Doutor da Disciplina de Reumatologia da Escola Paulista de Medicina da Universidade Federal de São Paulo (UNIFESP) 